\title{
The Kræmer $\varnothing$ syenite, Kangerdlugssuaq: preliminary description of one of the voluminous oversaturated syenites of the East Greenland Tertiary
}

\author{
C. KENT BROOKS
}

\begin{abstract}
Brooks, C. K.: The Kræmer $\emptyset$ syenite, Kangerdlugssuaq: preliminary description of one of the voluminous oversaturated syenites of the East Greenland Tertiary. Bull. geol. Soc. Denmark, Vol. 38, pp. 145-151, Copenhagen, February 18th, 1991. https://doi.org/10.37570/bgsd-1990-38-13

The Kræmer $\emptyset$ syenite, situated close to the Skaergaardintrusion, is typical of many oversturated syenites in the area. It consists of a maginal breccia with a sharp contact to the surrounding gneisses. This breccia, about $150 \mathrm{~m}$ wide is made up of basaltic clasts in a granitic matrix. It is associated with pegmatites, aplites and granophyres, all with a non-peralkaline characters. The main part of the syenite is a coarse-grained, massively jointed body with many large basic xenoliths and occasional modal layering. It is associated with peralkaline rhyolitic dikes and pegmatites. Anatexis of basement and crystal differentiation from a basaltic magma are thought to be unlikely processes to explain the origin of the syenites although the breccia matrix appears to be a simple partial melt of the gneisses. It is postulated that such an anatectic melt, formed by heat transfer from basaltic magmas, becomes modified by diffusive interchange with the basaltic melt to generate the syenite in the way described for a nearby locality by Nielsen \& Brooks(1988).
\end{abstract}

C. K. Brooks, Institut for Petrologi, Øster Voldgade 10, DK-1350 Copenhagen K, Denmark. April 10th, 1987.

One of the most intractable problems in igneous petrology has proved to be the origin of nonorogenic or " $A$ " type granites. For instance, in the Hebridean sector of the North Atlantic Tertiary province, the granites of Skye have been variously interpreted as crustal melts or differentiation products of the locally voluminous basaltic magmas; a question which has been attacked with the entire armoury of modern petrological techniques (for a summary, see Bell, 1976). At the present time, most workers seem to agree that at least some crystal component is present (Thompson, 1982), and the same is true of the felsic rocks associated with the Skaergard intrusion in East Greenland (Leeman \& Dasch, 1978), a locality close to that described here.

Of even greater uncertainty is the origin of syenitic rocks, which are particularly abundant in the East Greenland sector of the North Atlantic province (Brooks \& Nielsen, 1982; Nielsen, 1987). Syenites have traditionally been regarded as differentiates of mantle-derived basic magmas (e.g. Wilkinson, 1966) because: a) they often occur in small quantities associated with large amounts of alkali basaltic magma, b) they often show geochemical characteristics in common with the associated basic rocks, c) they are often, at least in part, peralkaline, a characteristic difficult to envisage arising from metaluminous continental crust, d) they occur on oceanic islands remote from such crust and e) they do not corresposnd to minimum melts of sialic crust.

In contrast to this prevalent view, the Kangerdlugssuaq syenites show many field characteristics which indicate that they are derived from the local basement gneisses. Because of the general inaccessability of the area, few detailed descriptions are available and this note presents field and some geochemical data on one of these bodies, one which is probably typical for the area in most respects.

\section{Location and setting}

The Kræmer $\varnothing$ syenite is a $3.5 \mathrm{~km}$ by $1.6 \mathrm{~km}$ exposure situated some $7 \mathrm{~km}$ west of the contact of the Skaergard intrusion. An unknown, but probably major part of the intrusion, lies under the waters of Kangerdlugssuaq and its relations to the syenite of Bagnæsset and small syenite 


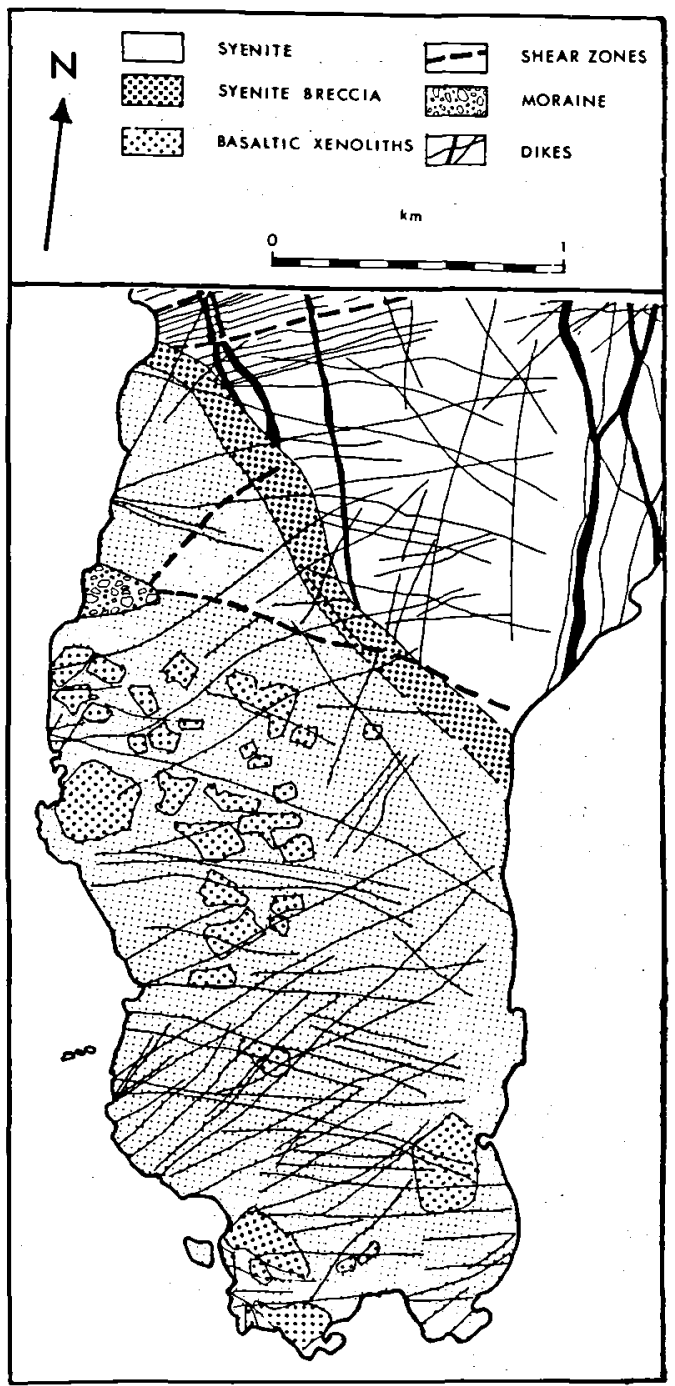

Fig. 1. Map of Kræmer $\emptyset$ syenite (drawn from air photographs by T. F. D. Nielsen.

exposures along the shore on the northern side of Amdrup Pynt on the opposite side of the fjord is unknown. (For place names and general geological setting, see Brooks \& Nielsen, 1982).

\section{Country rocks}

The basement in the Kangerdlugssuaq area consists in general of quartzo-feldspathic gneisses with amphibolite facies mineralogy and commonly showing agmatitic structures. At the northern end of Kræmer $\varnothing$, metasediments occur with sillimanite pseudomorphs after kyanite and
Fe-rich paragenesses with garnet, pyroxene and quartz. Several workers (see references below) have attempted to refine the geochronology of these rocks: they are certainly Archaean, but precise relationships have not yet been reported.

\section{Marginal breccia zone}

Structures in the gneiss, trending $70^{\circ}$ and dipping $20^{\circ} \mathrm{S}$, continue undisturbed up to the contact, which is knife sharp. The intrusive event was thus entirely one of brittle fracture. Inside the contact, a $150 \mathrm{~m}$ wide zone tightly packed angular, largely basic blocks supported by a granitic matrix follows the contact over its entire $2 \mathrm{~km}$ exposure. The granitic matrix is very inhomogenous and often shows ghost structures reminiscent of gneissic foliation. Only a few dikes, identified as the late ALK-2 generation (Nielsen, 1978) cut the intrusion. In particular, the Skaergaard-like dikes described by Brooks \& Nielsen (1978) are truncated by the intrusion.

Breccias are common in the marginal zones of other syenites in the Kangerdlugssuaq area (e.g. the Kap Boswell syenite - see map in Abbot \& Deer, 1972). They are also extensively developed at Kialineq, $150 \mathrm{~km}$ to the south (Brooks, 1977, Brown \& Becker, 1986). Such breccias are of several types: net-veined types, in which angular clasts may be fitted back together, pillowed complexes (basic pillows with chilled, crenulate margins in a felsic matrix) and chaotic assemblages such as the one described here. These types may occur in combinations.

\section{Main syenite}

This is a homogeneous, coarse-grained, hypersolvus syenite with a brownish weathering colour. It shows massive, cyclopean jointing, which weathers out to form impressive canyons (e.g. at the southern tip of the outcrop, Jagtlejren, called in Greenlandic "Kupativat" = "the Fissures"). Huge, angular basic inclusions are scattered haphazardly throughout the body (Fig. 1) while gneiss inclusions are small and rare. The basaltic inclusions are assumed to originate in a roof which has since been stripped away by erosion, but they frequently consist of a pyroxene-phyric rock, which is unknown in the existing basalts. 
Table 1. Kraemer $\emptyset$ : composition of syenites.

\begin{tabular}{|c|c|c|c|c|c|c|c|c|c|c|c|}
\hline & 20386 & 27025 & 30003 & 40586 & 27715 & 27730 & 27867A & 40587 & 27708 & 27120 & 271212 \\
\hline $\mathrm{SiO}_{2}$ & 64.85 & 66.26 & 64.95 & 66.29 & 64.59 & 65.25 & 65.71 & 67.60 & 71.23 & 65.74 & 65.14 \\
\hline $\mathrm{Al}_{2} \mathrm{O}_{3}$ & 15.35 & 15.87 & 14.73 & 14.20 & 14.11 & 13.95 & 14.99 & 13.91 & 13.07 & 14.23 & 15.41 \\
\hline $\mathrm{Fe}_{2} \mathrm{O}_{3}$ & 2.16 & 0.99 & 0.97 & 1.13 & 1.37 & 0.63 & 2.78 & 1.40 & 1.35 & 0.96 & 1.10 \\
\hline $\mathrm{FeO}$ & 2.70 & 2.85 & 4.76 & 3.66 & 4.58 & 4.61 & 3.34 & 2.99 & 2.18 & 4.36 & 3.49 \\
\hline $\mathrm{MgO}$ & 0.25 & 0.27 & 0.39 & 0.42 & 0.51 & 0.35 & 0.28 & 0.22 & 0.15 & 0.38 & 0.21 \\
\hline $\mathrm{CaO}$ & 1.43 & 1.05 & 1.61 & 1.30 & 1.63 & 1.53 & 1.60 & 1.12 & 0.53 & 1.62 & 1.31 \\
\hline $\mathrm{Na}_{2} \mathrm{O}$ & 4.87 & 5.62 & 5.45 & 5.62 & 5.39 & 5.44 & 4.51 & 5.11 & 4.77 & 5.44 & 5.58 \\
\hline $\mathrm{K}_{2} \mathrm{O}$ & 6.55 & 4.76 & 4.97 & 5.08 & 4.77 & 4.91 & 5.08 & 5.41 & 5.09 & 4.88 & 5.57 \\
\hline $\mathrm{MnO}$ & 0.18 & 0.13 & 0.35 & 0.20 & 0.30 & 0.27 & 0.28 & 0.20 & 0.12 & 0.19 & 0.15 \\
\hline $\mathrm{TiO}_{2}$ & 0.61 & 0.45 & 0.78 & 0.73 & 0.87 & 0.76 & 0.79 & 0.58 & 0.31 & 0.77 & 0.58 \\
\hline $\mathrm{P}_{2} \mathrm{O}_{5}$ & 0.10 & 0.45 & 0.19 & 0.13 & 0.26 & 0.22 & 0.12 & 0.05 & 0.12 & 0.16 & 0.07 \\
\hline volat. & 0.24 & 0.03 & 0.49 & 0.53 & 0.46 & 0.44 & 0.45 & 0.58 & 0.26 & 0.56 & 0.66 \\
\hline sum & 99.05 & 99.33 & 99.64 & 99.29 & 98.84 & 98.36 & 99.93 & 99.17 & 99.18 & 99.29 & 99.27 \\
\hline \multicolumn{12}{|c|}{ C.I.P.W. weight norm } \\
\hline $\mathbf{Q}$ & 8.40 & 10.65 & 8.63 & 10.38 & 9.88 & 9.87 & 15.46 & 14.21 & 22.36 & 10.47 & 7.43 \\
\hline or & 38.71 & 28.13 & 29.37 & 30.02 & 28.19 & 29.02 & 30.02 & 31.97 & 30.08 & 28.84 & 32.92 \\
\hline$a b$ & 41.21 & 47.56 & 46.12 & 44.76 & 45.61 & 44.42 & 38.16 & 41.43 & 38.89 & 46.03 & 47.22 \\
\hline an & 0.68 & 4.02 & 1.05 & - & 0.22 & - & 5.65 & - & - & . $\quad-$ & 0.55 \\
\hline $\mathrm{ac}$ & - & - & - & 2.46 & - & 1.42 & - & 1.59 & 1.32 & - & - \\
\hline di & 4.98 & 0.87 & 4.98 & 4.87 & 5.36 & 4.40 & 1.30 & 4.58 & 1.62 & 6.11 & 4.82 \\
\hline hy & 0.55 & 5.36 & 5.67 & 4.17 & 4.89 & 5.64 & 3.08 & 2.36 & 2.50 & 4.06 & 2.82 \\
\hline $\mathrm{mt}$ & 3.13 & 0.72 & 1.41 & 0.40 & 1.99 & 0.20 & 4.03 & 1.23 & 1.31 & 1.39 & 1.59 \\
\hline il & 1.16 & 0.95 & 1.48 & 1.39 & 1.65 & 1.44 & 1.50 & 1.10 & 0.59 & 1.46 & 1.10 \\
\hline ap & 0.23 & 0.07 & 0.44 & 0.30 & 0.60 & 0.51 & 0.28 & 0.12 & 0.28 & 0.37 & 0.16 \\
\hline
\end{tabular}

Table 2. Kraemer $\emptyset$ : Marginal zone and related rocks.

\begin{tabular}{|c|c|c|c|c|c|c|c|c|}
\hline & 27712 & 30004 & 30006 & 27716 & 27713 & 27126 & 27709 & 27711 \\
\hline $\mathrm{SiO}_{2}$ & 67.57 & 75.20 & 72.45 & 75.63 & 75.99 & 76.02 & 73.92 & 75.90 \\
\hline $\mathrm{Al}_{2} \mathrm{O}_{3}$ & 13.45 & 13.41 & 12.77 & 12.70 & 11.92 & 11.83 & 14.40 & 13.27 \\
\hline $\mathrm{Fe}_{2} \mathrm{O}_{3}$ & 3.17 & 0.00 & 1.80 & 0.43 & 0.87 & 1.15 & 0.05 & - \\
\hline $\mathrm{FeO}$ & 3.37 & 1.03 & 1.56 & 0.80 & 0.80 & 0.65 & 0.67 & 1.09 \\
\hline $\mathrm{MgO}$ & 0.29 & 0.00 & 0.09 & 0.07 & 0.08 & 0.00 & 0.22 & 0.11 \\
\hline Cao & 1.21 & 0.37 & 0.56 & 0.32 & 0.17 & 0.43 & 0.69 & 0.43 \\
\hline $\mathrm{Na}_{2} \mathrm{O}$ & 5.12 & 4.56 & 2.66 & 4.29 & 3.91 & 3.46 & 4.45 & 5.30 \\
\hline $\mathrm{K}_{2} \mathrm{O}$ & 3.48 & 4.51 & 7.01 & 4.65 & 4.96 & 5.16 & 4.89 & 3.29 \\
\hline MnO & 0.17 & 0.09 & 0.12 & 0.04 & 0.05 & 0.01 & 0.02 & 0.03 \\
\hline $\mathrm{TiO}_{2}$ & 0.77 & 0.01 & 0.40 & 0.07 & 0.09 & 0.13 & 0.04 & 0.02 \\
\hline $\mathrm{P}_{2} \mathrm{O}_{5}$ & 0.13 & 0.00 & 0.07 & 0.02 & 0.05 & 0.01 & 0.02 & - \\
\hline volat. & 0.32 & 0.53 & 0.23 & 6.38 & 0.18 & 0.36 & 0.42 & 0.41 \\
\hline sum & 99.05 & 99.71 & 99.72 & 99.40 & 99.07 & 99.21 & 99.69 & 99.85 \\
\hline \multicolumn{9}{|c|}{ C.I.P.W. weight norm } \\
\hline $\mathbf{Q}$ & 20.99 & 26.69 & 28.61 & 31.66 & 33.64 & 35.35 & 27.00 & 30.47 \\
\hline or & 20.57 & 26.65 & 41.43 & 27.48 & 29.31 & 30.49 & 28.90 & 19.44 \\
\hline$a b$ & 43.33 & 38.59 & 22.51 & 36.30 & 33.09 & 29.28 & 37.66 & 44.85 \\
\hline an & 3.44 & 1.84 & 2.20 & 1.46 & 0.33 & 1.51 & 3.29 & 2.13 \\
\hline $\mathrm{av}$ & - & - & - & - & - & - & - & - \\
\hline di & 1.48 & - & 0.10 & - & 0.16 & 0.09 & - & - \\
\hline hy & 2.58 & 2.04 & 1.11 & 1.25 & 0.83 & 0.19 & 1.79 & 2.30 \\
\hline $\mathrm{mt}$ & 4.60 & - & 2.61 & 0.62 & 1.26 & 1.67 & 0.07 & - \\
\hline il & 1.46 & 0.02 & 0.86 & 0.13 & 0.17 & 0.25 & 0.08 & 0.04 \\
\hline ap & 0.03 & - & 0.16 & 0.05 & 0.12 & 0.02 & 0.05 & 0.21 \\
\hline
\end{tabular}


Table 3. Kraemer $\varnothing$ : compositions of peralkaline rhyolites, etc.

\begin{tabular}{|c|c|c|c|c|c|c|c|}
\hline & 27653 & $\begin{array}{l}27710 \\
\text { green }\end{array}$ & 27046 & 30005 & $\begin{array}{l}27710 \\
\text { white }\end{array}$ & 27725 & 27124 \\
\hline $\mathrm{SiO}_{2}$ & 73.33 & 72.68 & 74.17 & 75.26 & 75.31 & 75.28 & 75.28 \\
\hline $\mathrm{Al}_{2} \mathrm{O}_{3}$ & 11.96 & 10.65 & 11.68 & 11.70 & 11.03 & 11.38 & 10.85 \\
\hline $\mathrm{Fe}_{2} \mathrm{O}_{3}$ & 1.07 & 4.31 & 1.76 & 1.04 & 1.99 & 0.72 & 2.04 \\
\hline $\mathrm{FeO}$ & 2.18 & 10.36 & 1.63 & 1.08 & 0.48 & 1.33 & 1.34 \\
\hline $\mathrm{MgO}$ & 0.05 & 0.04 & 0.14 & 0.00 & 0.05 & 0.05 & 0.00 \\
\hline $\mathrm{CaO}$ & 0.49 & 0.12 & 0.39 & 0.17 & 0.06 & 0.53 & 0.02 \\
\hline $\mathrm{Na}_{2} \mathrm{O}$ & 4.24 & 5.18 & 4.56 & 4.91 & 5.10 & 4.05 & 4.93 \\
\hline $\mathrm{K}_{2} \mathrm{O}$ & 5.25 & 4.68 & 4.50 & 4.08 & 3.75 & 4.52 & 4.07 \\
\hline $\mathrm{MnO}$ & 0.10 & 0.06 & 0.10 & 0.13 & 0.18 & 0.05 & 0.10 \\
\hline $\mathrm{TiO}_{2}$ & 0.32 & 0.20 & 0.31 & 0.06 & 0.22 & 0.17 & 0.15 \\
\hline $\mathrm{P}_{2} \mathrm{O}$ & 0.10 & 0.09 & 0.01 & 0.00 & 0.06 & 0.05 & 0.01 \\
\hline volat. & 0.30 & 0.04 & 0.49 & 0.65 & 0.14 & 0.26 & 0.27 \\
\hline sum & 99.39 & 98.53 & 99.74 & 99.08 & 99.28 & 98.39 & 99.06 \\
\hline \multicolumn{8}{|c|}{ C.I.P.W. weight norm } \\
\hline $\mathbf{Q}$ & 27.29 & 28.06 & 29.15 & 31.10 & 32.00 & 33.20 & 32.53 \\
\hline Or & 31.03 & 27.66 & 26.59 & 24.11 & 22.16 & 26.71 & 24.05 \\
\hline $\mathrm{Ab}$ & 32.29 & 28.73 & 35.03 & 37.47 & 3.86 & 33.37 & 33.15 \\
\hline Ac & 3.10 & 12.47 & 1.23 & 3.01 & 5.76 & 0.79 & 5.90 \\
\hline Ns & 0.02 & 0.22 & 0.50 & 0.15 & 0.18 & - & 0.43 \\
\hline $\mathrm{Di}$ & 1.58 & 0.01 & 1.65 & 0.75 & - & 2.03 & 0.03 \\
\hline Hy & 2.95 & 0.76 & 4.35 & 1.73 & 2.65 & 0.94 & 2.38 \\
\hline Mt & - & - & - & - & - & 0.65 & - \\
\hline Il & 0.61 & 0.38 & 0.59 & 0.11 & 0.42 & 0.65 & 0.28 \\
\hline Ap & 0.23 & 0.21 & 0.02 & - & 0.35 & 0.12 & 0.02 \\
\hline
\end{tabular}

Bleached zones are observed adjacent to these inclusions. Layering is observed in the syenites at a number of localities. This arises from variations in the concentrations of ferromagnesian mineral on a scale of a few centimetres. The layering strikes roughly parallel to the contact and dips about $20^{\circ}$ to the south.

The contact with the breccia envelope is not sharp, but takes place over a few decimetres with a rise in grain size; a fall in the quartz concentration and the effective disappearance of the basaltic clasts.

\section{Acid dikes}

These consist of pegmatites, rhyolites and microgranites. Some are apparently associated with the marginal zone as they are not found cutting the syenites, only the marginal breccias and country rocks. These are chiefly aplites and granophyres, although one body has a pegmatitic centre containing green (amazonite) feldspar. All are metaluminous, in contrast to those associated with the main syenite which are invariably peralkaline as identified by their content of aegirine, arfvedsonite and other typical minerals. These peralkaline bodies include blueish rhyolitic dikes and pinch-an-swell pegmatities containing abundant quartz, arfvedsonite, zircon and astrophyllite as described by Brooks and Rucklidge (1974). The astrophyllite from one of the pegmatites has been described by Layne et al. (1982).

\section{Chemistry}

Two previous analyses from Kræmer $\varnothing$ were reported by Deer \& Kempe (1976) but these are both corundum-normative, suggesting that they are not fresh. None of the samples analysed in this study, neither from Kræmer $\varnothing$ nor any other syenite in the area, is corundum-normative probably because most of the samples were collected by blasting. New chemical data (major elements) are reported in Tables 1-3 and plotted in Fig. 2 (normative $\mathrm{Q}-\mathrm{Or}-\mathrm{Ab}$ ) and Fig. 3 (molecular $\mathrm{SiO}_{2}-\mathrm{Al}_{2} \mathrm{O}_{3}$-alkalies).

The syenites (Table 1 ) are a fairly homogeneous group lying on both sides of the line dividing 


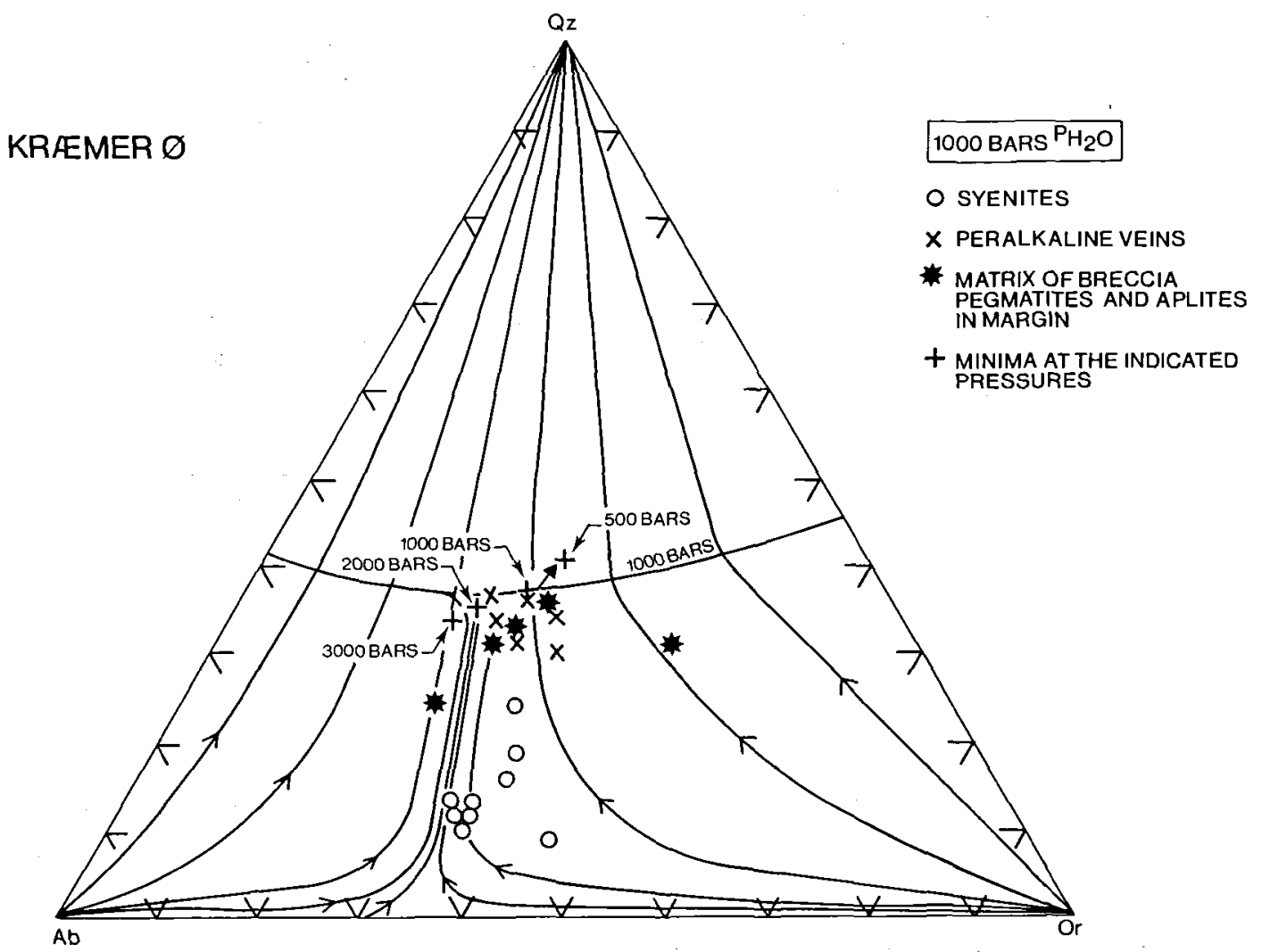

Fig. 2. The granite system at a water vapour pressure of 1000 bars (after Tuttle \& Bowen, 1958). Curves showing trends of ideal fractional crystallization are shown together with minima at other watervapour pressures. The arrow shows the direction of movement of the peralkaline samples with devitification (see Brooks \& Rucklidge, 1976).

peralkaline from non-peralkaline compositions $\left(\mathrm{SiO}_{2}\right.$-alkali feldspar in fig. 3) and well removed from the area of possible minimum melts in the granitic system (fig. 2). The acid matrix to the breccia and its associated pegmatites and aplites (Table 2) plot closer to the minimum melt compositions although there is considerable spread. All these rocks are non-peralkaline (fig. 3). Dikes associated with the syenite (Table 3 ) are all peralkaline and lie close to minimum melt compositions in fig. 2). The peralkalinity allows these dikes to be recognized as a group even outside the area of the main syenite, but this character may be lost by secondary effects as described by Brooks \& Rucklidge (1974).

\section{Petrogenesis}

The Kræmer $\emptyset$ syenite is typical of many syenite bodies in this area and an understanding of its origins would be applicable to the area as a whole.

It might be postulated that nordmarkitic syenites of this type form either by fractionation of basaltic magma or by melting of continental crust. Neither of these ideas is satisfactory: the first because of the large volumes of syenite in the area (Brooks \& Nielsen 1982) and the isotopic relations (see below), the second because the compositions are not what would be expected, being too alkali rich. In fact, it has always been something of a problem to explain why syenites should be so common when they plot on a thermal high in petrogeny's residua system (quartznepheline-kalsilite, see Morse, 197 ?

Whatever the mechanism by which these rocks have formed, it seems clear that they have received an addition of alkalies. Previous workers in other areas have suggested formation by partial melting of basement gneisses which have been enriched in alkalies by volatile fluxing from 


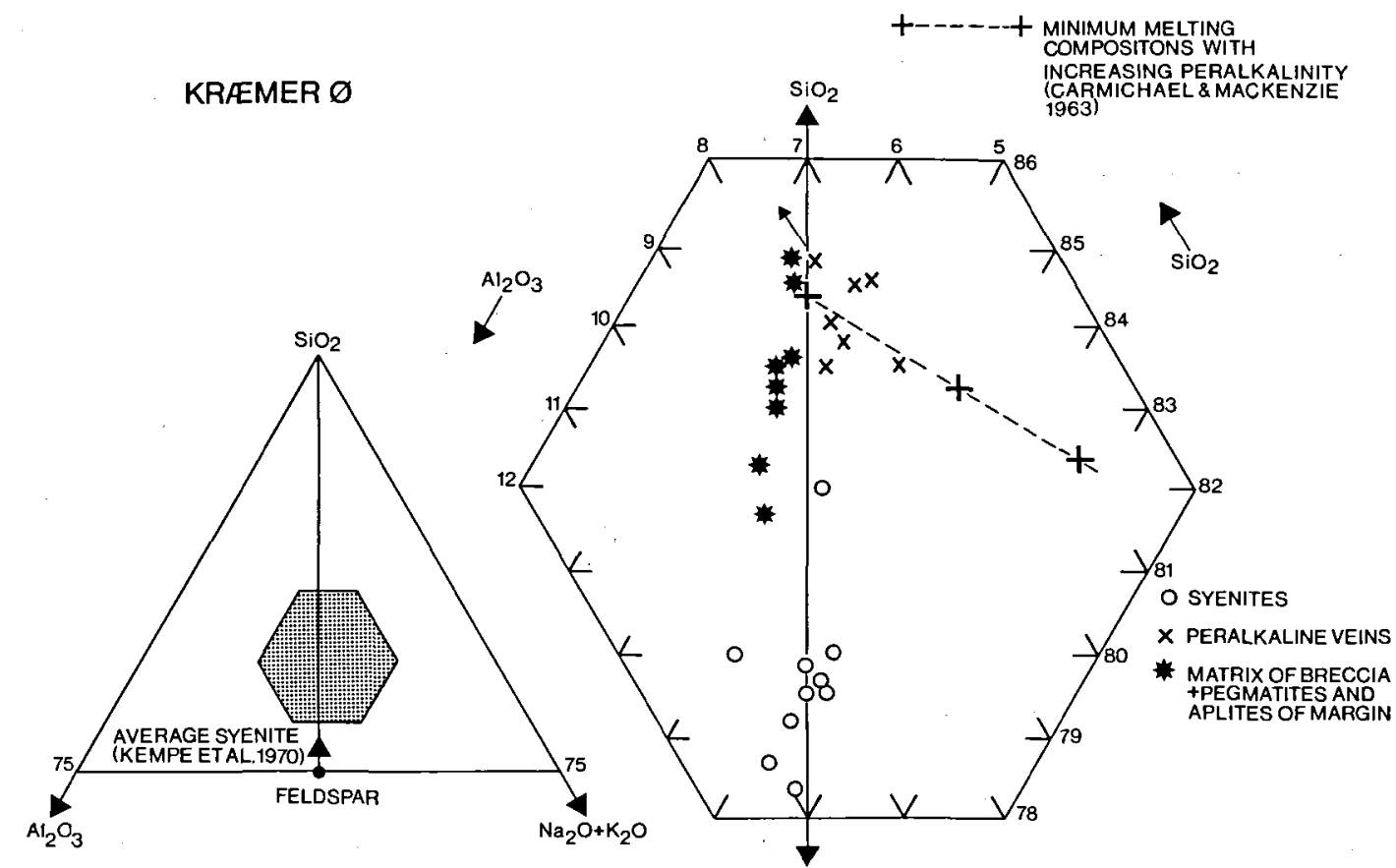

Fig. 3. Molecular $\mathrm{SiO}_{2}-\mathrm{Al}_{2} \mathrm{O}_{3}$-total alkalies after Bailey \& Macdonald (1969). Arrow again shows loss of peralkalinity with alteration (see fig. 2). Point labelled "average syenite (Kempe et al., 1970)" refers to estimated average composition of Kangerdlugssuaq intrusion.

the mantle (e.g. Harris \& Merrimer, 1960). This is an unsatisfactory model as there is no evidence for such fenitized basement which must therefore be referred to deep levels in the crust. We suggest as a working model that the syenite melts are formed by crustal anatexis combined with diffusive exchange with basaltic magmas as described by Watson (1976) and Lesher (1986), and proposed for a nearby occurrence in a companion paper (Nielsen \& Brooks, 1988). At Kræmer $\emptyset$, the marginal zone may well include straight partial melts of the gneisses: their compositions are broadly consistent with this, as is the presence of ghost gneissic foliation in the breccia matrix. Furthermore, their location in the contact zones caused rapid cooling and thus little possibility of diffusive interaction. The main syenite on the other hand was able to cool slowly, equilibrate with other magmas and even differentiate to give the peralkaline rhyolites and pegmatites.

Unpublished Sr isotope data by R. D. Beckinsale on the samples described here are consistent with this view. Five samples of syenite have initial (i.e. at $50 \mathrm{Ma}$ ago) ${ }^{87} \mathrm{Sr} /{ }^{86} \mathrm{Sr}$ ratios in the range 0.709-0.719 whereas samples from the breccia matrix have this value ranging from 0.716 to 0.865 . One of these latter samples plot on a late Archaean isochron as determined for the surrounding basement by Pankhurst et al. (1976), Leeman \& Dasch (1978) and Lars C. Larsen (unpublished). This sample is, at leaast in terms of $\mathrm{Sr}$ isotopes, pure remelted basement whereas others appear to be mixtures of this ancient $\mathrm{Sr}$ and more recent mantle derived $\mathrm{Sr}$.

The model proposed here, whereby basic magmas supply heat to the basement generating melts which then undergo diffusive exchange, has the advantage that it can be observed in a arrested stage nearby (Nielsen \& Brooks, 1988). In the case of the Kræmer $\varnothing$ syenite it is not possible to test the model fully at the present time due to lack of sufficient data, notably trace elements, espceially rare eartly elements. It is intended also to acquire data on stable isotopes and further radiogenic isotope data.

The undersaturated syenites, such as the foyaites of the Kangerdlugssuaq intrusion (Kempe et al. 1970) can probably not be formed in this way. Instead, they may arise by differentiation of nephelinitic magmas as suggested by 


\section{Brooks \& Gill (1982). However, such syenites are volumetrically of much lesser importance.}

Acknowledgements. Sample collection using dynamite was carried out with the help of J.C. Rucklidge. R. D. Beckinsale is thanked for access to his unpublished $\mathrm{Sr}$ isotope determinations and field work is East Greenland is carried out with the financial support of the Danish Natural Science Research Council.

\section{Dansk sammendrag}

- Overmattede syeniter er en vigtig bjergartstype i den østgrønlandske tertiar. Deres oprindelse er uklart. her beskrives et typisk eksempel som består af en ydre breccia zone med mafiske klaster $i$ en granitisk matrix, en indre massiv syenit og en rakke gange af forskellige typer. Der konkluderes at breccia matrixen er dannet ved opsmeltning af den prekambriske grundfjeld og syeniten er dabbet på lignende vis men kombineret med diffusive udveksling med den basiske magma som har forårsaget opsmeltning. Peralkaline gange af forskellige slags er differentiations produkter af syeniten.

\section{References}

Abbott, D. \& Deer, W. A. 1972: Geological investigations in East Greenland. Part X. The gabro cumulates of the Kap Edvard Holm lower layered series. Meddr. Gronland 190 (6), $42 \mathrm{pp}$.

Bailey, D. K. \& Macdonald, R. 1969: Alkali feldspar fractionation trend and the derivation of peralkaline liquids. Amer. J. Sci. 267, 242-248.

Bell, J. D. 1976: The Tertiary intrusive complex on the Isle of Skye. Proc. Geol. Assoc. 87, 248-271.

Brooks, C. K. 1977: Example of magma mixing from the Kialineq district of East Greenland. Bull. geol. Soc. Denmark $26,77-83$.

Brooks, C. K. \& Gill, R.C.O. 1982: Compositional variation in the pyroxenes and amphiboles of the Kangerdlugssuaq intrusion, East Greenland: Further evidence for the crustal contamination of a syenite magma. Mineral. Mag. 45, 1-9.

Brooks, C. K. \& Nielsen, T. F. D. 1978: Early stages in the differentiation of the Skaergaard magma as revelaed by a closely related suite of dike rocks. Lithos 11, 1-14.

Brooks, C. K. \& Nielsen, T. F. D. 1982: The Phanerozoic development of the Kangerdlugssuaq area, East Greenland. Meddr. Gronland Geosci. 9, 30 pp.
Brooks, C. K. \& Rucklidge, J. C. 1976: Tertiary peralkaline rhyolite dikes from the Skaergaard area, Kangerdlugssuaq, East Greenland. Meddr. Gronland 197(3), 27 pp.

Brown, P.E. \& Becker, S.M. 1986: Fractionation, hybridization and magma mixing in the Kialineq centre, East Greenland. Contrib. Mineral. Petrol. 92, 92, 57-70.

Deer, W. A. \& Kempe, D.R.C. 1976: Geological investigations in East Greenland. Part XI. The minor peripheral intrusions, Kangerdlugssuaq, East Greenland. Meddr. Gronland 197(4), 25 pp.

Harris, N. B. W. \& Marrimer, G. F. 1980: Geochemistry and petrogenesis of a peralkaline granite complex from the Midian Mountains, Saudi Arabia. Lithos 13, 325-337.

Kempe, D. R. C., Deer, W. A. \& Wager, L.R. 1970: Geological investigations in East Greenland. Part VIII. The petrology of the Kangerdlugssuaq alkaline intrusion, East Greenland. Meddr. Gronland 190 (2), 49 pp.

Layne, G. D., Rucklidge, J.C. \& Brooks, C. K. 1982: Astrophyllite from Kangerdlugssuaq, East Greenland, Mineral. Mag. 45, 149-156.

Leeman, W. P. \& Dasch, E. J. 1978: Strontium, lead and oxygen isotopic investigations of the Skaergard intrusion, East Greenland. Earth Planet. Sci. Lett. 41, 47-59.

Lesher, C.E. 1986: Effects of silicate liquid composition on mineraliquid element partition from Soret diffusion studies. J. geophys. Res. 91, 1397-1411.

Morse, S. A. 1969: Syenites. Carnegie Inst. Washington, Yearbook 67, 112-126.

Nielsen, T. F. D. 1978: The Tertiary dyke swarms of the Kangerdlugssuaq area, East Greenland: an example of magmatic development during continental break-up. Contrib. Mineral. Petrol. 67, 63-78.

Nielsen, T.F.D. 1987: Tertiary alkaline magmatism in East Greenland: a review. In Fitton, J.G. \& Uptaon, B. G. J. (eds.) Alkaline Igneous Rocks. Geol. Soc. Spec. Publ., $489-515$ (in press).

Nielsen, T. F. D. \& Brooks, C. K. 1988: Generation of nordmarkitic melts by melting of basemeent gneisse: the Astrophyllite Bay complex, Kangerdlugssuaq. Bull. geol. Soc. Denmark (this volume).

Thompson, R.N. 1982: Magmatism of the British Tertiary volcanic Province. Scot. J. Geol. 18, 50-107.

Tuttle, O.F. \& Bowen, N. L. 1958: Origin of granite in the light of experimental studies in the system $\mathrm{NaAlSi}_{3} \mathrm{O}_{8}$ $\mathrm{KAISi}_{3} \mathrm{O}_{8}-\mathrm{SiO}_{2}-\mathrm{H}_{2} \mathrm{O}$. Geol. Soc, Am. Memoir 74, $152 \mathrm{pp}$.

Watson, E. B. 1976: Two liquid partition coefficients. Contrib. Mineral. Petrol. 56, 119-134.

Wilkinson, J.F.G. 1966: Residual glasses from some alkali basaltic lavas from New South Wales. Mineral. Mag. 35, $847-860$. 